
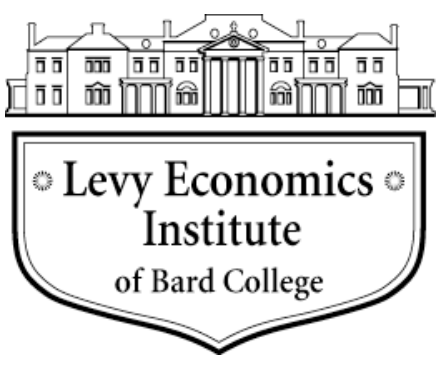

Working Paper No. 855

\title{
The Two Approaches to Money: Debt, Central Banks, and Functional Finance
}

by

Giuseppe Mastromatteo

Institute of Political Economy, Catholic University of the Sacred Heart

\section{Lorenzo Esposito*}

Bank of Italy, Milan

November 2015

* The views expressed are those of the author and do not necessarily reflect the position of the Bank of Italy.

The Levy Economics Institute Working Paper Collection presents research in progress by Levy Institute scholars and conference participants. The purpose of the series is to disseminate ideas to and elicit comments from academics and professionals.

Levy Economics Institute of Bard College, founded in 1986, is a nonprofit, nonpartisan, independently funded research organization devoted to public service. Through scholarship and economic research it generates viable, effective public policy responses to important economic problems that profoundly affect the quality of life in the United States and abroad.

Levy Economics Institute

$$
\text { P.O. Box } 5000
$$

Annandale-on-Hudson, NY 12504-5000

http://www.levyinstitute.org

Copyright $(C$ Levy Economics Institute 2015 All rights reserved 


\section{ABSTRACT}

The scientific reassessment of the economic role of the state after the crisis has renewed interest in Abba Lerner's theory of functional finance (FF). A thorough discussion of this concept is helpful in reconsidering the debate on the nature of money and the origin of the business cycle and crises. It also allows a reevaluation of many policy issues, such as the Barro-Ricardo equivalence, the cause of inflation, and the role of monetary policy.

FF, throwing a different light on these issues, can provide a sound foundation for discussing income, fiscal, and monetary policy rules in the right context of flexibility in the management of national budgets, assessing what kind of policies should be awarded priority, and the effectiveness of tackling the crisis with the different part of public budget. It also allows us to understand ways of increasing efficiency through public investment while reducing the total operational costs of firms. In the specific context of the eurozone, FF is useful for assessing the institutional framework of the euro and how to improve it in the face of protracted low growth, deflation, and weak public finances.

Keywords: Crisis; Functional Finance; Debt; Growth; Sustainability of Public Finance; Central Bank Independence

JEL Classifications: B22, E62, E63 


\section{INTRODUCTION: DYSFUNCTIONAL FINANCE ${ }^{1}$}

After at least three decades where mainstream laissez-faire economics served to mold banking regulation and public policies as a whole, the financial system collapsed, pushing the world economy to the brink of the abyss. Suddenly, economists, central banks, and the government were forced to acknowledge how dysfunctional the characteristics of the world financial system were. In a system where profitability was tantamount to efficiency, it became clear that, even without considering implicit subsidies like deposit insurance and lending of last resort, banking is not as profitable as it seems and maybe is not profitable at all (Haldane 2010). It is also clear that big banks had amassed such colossal political power that they captured everything in their path, including regulators and government (Kay 2009). So much for financial market efficiency.

All mainstream conclusions supposedly carved in stone are now suspicious. This is already true in practice, as policymakers were forced to follow different directions. The new situation also encouraged a revival of old debates such as the long-abandoned question of whether it is effective to use deficit spending policies to spur economic growth and how to fund them. The resumption of functional finance (hereafter also FF) — that started even before the crisis (Goodhart 1998; Arestis and Sawyer 2003; Colander 2003; Forstater 2003)—is now widespread (Tcherneva 2008; Wray 2009c; Aspromourgos 2014). The expression was coined by Abba Lerner in 1943 reflecting the growing awareness of the policy implications of Keynes's General Theory. Lerner believed that the public budget should not only fulfil its traditional allocative tasks but should also address the problem of the stabilization of the cyclical trend of the economy. According to this theory, public finance should be functional to the long-term development of the system.

As Keynes pointed out (Aspromourgos 2014), FF is an idea more than a policy, a way to look at the role of the State and not a ready-made set of tools to deploy. This is very interesting because it allows the use of FF to reassess a number of theoretical debates. In particular, FF encourages economics to reconsider the nature of money with all the due consequences about public debt, inflation, the role of central banks, and so on. We will deal with all these issues as far as they are "functional" to establish the conceptual framework in which we discuss practical alternatives to the mainstream policies. All in all we will deepen historical economic controversies to show that there is a basic consistency in all the issues that the two theoretical frameworks face on the basis of their theory of money. Starting with policy implications of alternative views on the nature of money, we

\footnotetext{
${ }^{1}$ We would like to thank Prof. Giarda, Prof. Panico, Prof. Serravalli, Dr. Gatti, and participants at the XIX Annual Conference of the European Society for the History of Economic Thought held in Rome on May14-16, 2015.
} 
deal with monetary and fiscal policy, central banking institutional design, the nature of inflation, and the role of the State. We reach the conclusion that after the crisis "fiscal dominance" is not a subjective stance of the government or monetary authorities, it is a structural feature of the world economy.

\section{ALL THAT GLITTERS IS NOT MONEY}

Given that an economic system without money is nowhere to be seen, one could ask why on earth we have university courses like "monetary economics" as though we could have a "non-monetary" economics. The explanation is the endless rule of the quantity theory of money.

How much continuity/discontinuity is retrievable between the classical school and modern mainstream economics is a matter of long and hot debates among historians and economists alike. In the field of money, we can state that continuity prevails, as Napoleoni pointed out: "through the theory of money it is possible to underline a strong affinity between Ricardo and marginalist economics, and an equally strong opposition to Marx at both those positions” (Boffito 1973, IX; our translation). This is because the classical school, such as the modern mainstream economic paradigm, is based on Say's Law and the quantity theory of money (hereafter also QTM). The core aspect of QTM is that in a market economy use-values still prevail and money is only an efficient way to allow for use-values circulation. Hence money is a neutral veil and a general economic crisis is impossible. At the end of the day, capitalism is not qualitatively different from the most primitive society conceivable.

The best demonstration that classical and modern orthodox theories agree in the monetary field is that they reach the same policy prescriptions. For our purposes the most relevant are the following: inflation is a monetary phenomenon with no connection with real economy; the need for independent central banks; rules rather than discretion in economic policies; the Barro-Ricardo Equivalence (BRE); inefficacy of fiscal policy; and the deposit multiplier as a faithful description of how banks work. ${ }^{2}$ We will show how all these different aspects of the debate on the right economic policies are linked to the nature of money.

\footnotetext{
${ }^{2}$ We refer to the main works of Smith and Ricardo, to Boffito (1973), and to the anthology of Marx's thought on this topic, edited by de Brunhoff and Ewenczyk (1981).
} 
In Smith and Ricardo, money is the result of historical selection-linked to the division of laboramong different commodities. Smith (1776 [2007], 22-23) says:

“... every prudent man in every period of society, after the first establishment of the division of labour, must naturally have endeavoured to manage his affairs in such a manner as to have at all times by him, besides the peculiar produce of his own industry, a certain quantity of some one commodity or other, such as he imagined few people would be likely to refuse in exchange for the produce of their industry. Many different commodities, it is probable, were successively both thought of and employed for this purpose. In the rude ages of society, cattle are said to have been the common instrument of commerce... In all countries, however, men seem at last to have been determined by irresistible reasons to give the preference, for this employment, to metals above every other commodity”

If we accept Smith's explanation that gold was the fittest commodity to become money in the process of natural selection of a means of exchange, classical conclusions on monetary and fiscal policy are totally legitimate.

First of all this is true for inflation and central bank independence. Ricardo, in particular, was worried that the Bank of England (BoE) could create too much money (producing inflation and instability), because the State and the central bank can do nothing to improve the economy but they can damage it by printing too many banknotes. He wrote (1821 [2001], 257):

There is no point more important in issuing paper money, than to be fully impressed with the effects which follow from the principle of limitation of quantity. It will scarcely be believed fifty years hence, that Bank directors and ministers gravely contended in our times, both in parliament, and before committees of parliament, that the issues of notes by the Bank of England, unchecked by any power in the holders of such notes, to demand in exchange either specie, or bullion, had not, nor could have any effect on the prices of commodities, bullion, or foreign exchanges.

The power granted to the BoE is huge and dangerous: "Experience, however, shows, that neither a State nor a Bank ever have had the unrestricted power of issuing paper money, without abusing that power: in all States, therefore, the issue of paper money ought to be under some check and control; and none seems so proper for that purpose, as that of subjecting the issuers of paper money to the obligation of paying their notes, either in gold coin or bullion” (Ricardo 1821 [2001], 259). 
The most interesting point raised by Ricardo is that he looks at the gold standard as a way to put the central bank under control, a remark similar to the Keynes's idea of a monetary framework as a social convention that a former Governor of the Bank of Italy (Carli 1996, 189-90; our translation) brilliantly summarized as follows: "The gold standard in the period where he worked, was a system that presupposed a society organized in a certain way, with respected ruling classes; a system in which the protest was less violent than the one we know today.”

The gold standard or, in more modern versions, the Friedman rule and central bank independence, work if they are accepted by society at large. Only if they are politically and culturally hegemonic, the rules flowing from them are accepted but, as Ricardo (1821 [2001], 261) already underlined, the power to issue money is inherently discretionary: "In the present state of the law, [the Bank directors] have the power, without any control whatever, of increasing or reducing the circulation in any degree they may think proper: a power which should neither be intrusted to the State itself, nor to any body in it.”

As the genie of the lamp cannot be put back in the bottle, the only solution is independence: "in a free country, with an enlightened legislature, the power of issuing paper money, under the requisite checks of convertibility at the will of the holder, might be safely lodged in the hands of commissioners appointed for that special purpose, and they might be made totally independent of the control of ministers" (Ricardo 1821 [2001], 264).

Ricardo reached the same conclusions that Kydland-Prescott and Barro-Gordon also reached some 150 years after, disproving the common idea that mathematics makes economics more rigorous or powerful. On the contrary, in many fields the theory merely repeated the ideas of Ricardo and monetarism can be seen as "a sterile return to issues that were discussed, probably on a higher theoretical level, fifty years ago” (Ciocca 1987). This is true for the theory of money, because after Ricardo, we cannot see new or better analyses and conclusions.

In the decades after the death of Ricardo, the QTM victory can be seen in the success of the currency school with its legal outcome, Peel's Act of 1844, which so tightly restricted the supply of new banknotes that the government was forced to suspend it at every serious crisis (Kindleberger and Aliber 2005). The subsequent debates did not go further and we can say that even now "Menger's (1892) rational choice analysis of the evolution of monetary systems remains the basis for all neoclassical explanations of money’s existence” (Ingham 2001). 
What is true for money is also true for banks, as they are still "useless in an Arrow-Debreu world" (Freixas and Rochet 2008). In this conceptual framework, a bank is like a pensioner waiting for the money to be paid in his account so that he/she can start to spend (i.e., deposits precede the loans, and the bank is merely an intermediary among savers and borrowers) and what is true for the single bank (or household) is true for the system as a whole. The efficient market hypothesis and financial deregulation are a direct outcome of this conceptual framework.

To propose an alternative framework we should start from the fact that the Smith-Ricardo description of the "rude ages of society" is not an accurate historical portrait but a convenient myth, as anthropologists and historians have frequently explained to the orthodox economists (Wray 2004). Coins were invented after at least thirty centuries where another kind of money was in use: credit money. From these two different theories of money come different perspectives on political economy and public policies. As Goodhart (1998) puts it: "there has been a continuing debate between those who argue that the use of currency was based essentially on the power of the issuing authority (Chartalists) - i.e., that currency becomes money primarily because the coins or monetary instruments more widely are struck with the insignia of sovereignty, and not so much because they happen to be made of gold, silver and copper, or later of paper-and those who argue that the value of currency depends primarily, or solely, on the intrinsic value of the backing of that currency (Metallists).”

Goodhart also underscores that most economists are “M,” but most other scholars (e.g., anthropologists, numismatists, and historians) are “C.” For many centuries, money was a tool of the State (mostly a city State) to run the economy. In fact, besides and before money, we find other tools that are very similar, considering the differences in scientific and technical development, to the ones used in modern times in the field of economic planning. ${ }^{3}$ This system of social credit/debt is based on the reciprocal obligation between the State and its citizens where "credit and debt have nothing and never have had nothing to do with gold and silver” (Innes, in Wray 2004).

Even precious metals became money not because of their intrinsic value but because public institutions started to accept them as such (Hudson, in Wray 2004). It is this social mechanism that allows a piece of gold (or of paper) to be transformed in money, something that can extinguish

\footnotetext{
${ }^{3}$ We cite some texts among the countless on the argument: Gordon Childe (1950 [2004]), Liverani (2004), Algaze (2006), and Milano (2012).
} 
debts, preserve value, and give measure to any value (Ingham 2004; see also Hayes 2012). Credit is what really matters when discussing the financial system, not banknotes.

Just like the nature of money is different in this framework, this is also true for banks. A recent study by Bank of England economists McLeay, Radia, and Thomas (2014) explain: ${ }^{4}$

\begin{abstract}
In the modern economy, most money takes the form of bank deposits. But how those bank deposits are created is often misunderstood: the principal way is through commercial banks making loans. Whenever a bank makes a loan, it simultaneously creates a matching deposit in the borrower's bank account, thereby creating new money.
\end{abstract}

The reality of how money is created today differs from the description found in some economics textbooks:

- Rather than banks receiving deposits when households save and then lending them out, bank lending creates deposits.

- In normal times, the central bank does not fix the amount of money in circulation, nor is central bank money "multiplied up” into more loans and deposits.

“[...] One common misconception is that banks act simply as intermediaries, lending out the deposits that savers place with them [...] In fact, when households choose to save more money in bank accounts, those deposits come simply at the expense of deposits that would have otherwise gone to companies in payment for goods and services. Saving does not by itself increase the deposits or 'funds available' for banks to lend.”

“[...] Another common misconception is that the central bank determines the quantity of loans and deposits in the economy by controlling the quantity of central bank money-the so-called 'money multiplier' approach. In that view, central banks implement monetary policy by choosing a quantity of reserves.” (McLeay, Radia, and Thomas 2014)

This alternative theory of money and banking can be used as a basis to put forward a different conception of economic policy. We will show how to build this framework following the main theoretical points linked to money, being aware that, although the "facts" cannot directly decide a

\footnotetext{
${ }^{4}$ A number of central bankers and famous economists share this position (see: http://keynesblog.com/2013/03/26/inflazione-emoneta-5-le-banche-centrali-e-la-teoria-della-moneta-endogena/). See also Jakab and Kumhof (2015).
} 
theoretical dispute, after the crisis our case is easier and the mainstream conclusions less straightforward.

\section{THE NATURE OF INFLATION}

For classical economists, inflation or deflation was linked to a change in the cost of production of gold and silver but had nothing to do with economic activity in general. In the modern version of this idea (the quantity theory of fiat money), inflation is linked to excessive production of money by the central banks due to their attempt to violate economic laws (i.e., the QTM).

In a nutshell the mechanism is the following. If authorities believe that the Phillips curve represents the policy options they have, they will accept more inflation to increase employment. However, in the long run employment is linked to the structural economic dynamics and the attempt to print money to push economic growth will only increase prices. This idea of a long-term vertical Phillips curve (with its consequence: a "natural” rate of unemployment) was given a more sophisticated structure with the dynamic inconsistency debate. The inconsistency arises from the fact that if the QTM applies, it is futile to try reducing unemployment because involuntary unemployment only exists because the system is kept suboptimal by market imperfections.. The State cannot create more employment than markets already do. What it should do, if it should do something at all, is dispose of market imperfection (abolishing wage indexation, crushing unions, and so on). In other words, inflation is the wrong remedy for unemployment. Time inconsistency thus implies the least possible activism, as Kydland and Prescott (1977) point out: “The implication of this analysis is that, until we have such a theory, active stabilization may very well be dangerous and it is best that it not be attempted.” The general idea behind this hands-off approach (i.e., a long-term vertical Phillips curve) has been accepted by mainstream economists of all ages since Smith and Ricardo.

The difference is that while Hume or the Chicago teachers of Friedman were convinced of the efficacy of countercyclical policies (even if only for a short time), after Lucas the inefficacy paradigm had reached a temporal conclusions. Activism is always fruitless in every circumstance. The Phillips curve is always vertical unless markets are disturbed by imperfections.

If by construction activism is self-defeating and no one is surprised when the central bank tries to reduce unemployment by printing money, the solution is tying its hands to fixed rules so that everybody is assured that inflation will be low. As we have seen, this is nothing new: Ricardo 
already proposed it. Interestingly, Thornton, who was the finest monetary analyst of Ricardo's epoch, and who agreed with Ricardo on almost everything, was against fixed rules. We will come back to this point.

It is worth noting that monetary rules are based on absolute values: mainstream economics suggests objective functions in absolute terms and this is how they are formulated in practice. For instance, the ECB has a task of price stability defined as a "year-on-year increase in the Harmonised Index of Consumer Prices (HICP) for the euro area of below 2\%.” ${ }^{\circ 5}$ As the central bank should borrow its target from peoples' preferences, the theory is telling us that everybody is interested in an absolute level of inflation. But why should someone be interested in a particular level of inflation? Why is a percentage rate of inflation high or low? This is never properly explained. In our opinion, the only meaningful answer is that inflation is high for someone if it reduces his real income. For instance, if the employment contract states that automatic inflation adjustments are capped at 3\%, 4\% inflation is high. By the same token, if country A's trade partners have an inflation of, say 5\%, while it has $3 \%$, its inflation is low inasmuch as it improves its competitiveness, whereas if its partners have $2 \%$, the very same $3 \%$ inflation is high.

In other terms, while for mainstream economics the inflation target assigned to central banks is a kind of platonic ideal, in our framework it is basically a benchmark. The benchmark view should be obvious because that is how also financial markets work. For instance, is the yield of a given bond (say, 3\%) is high or low per se? The question makes no sense. A yield of $3 \%$ can be high or low depending on the prevailing interest rates for this asset class, the expected inflation (and therefore the real yield), and so on. Why should it be different for money? If we think about how the Maastricht Treaty parameters were built, we can see that they engender the benchmark assumption as the inflation parameter stated that inflation had to be no more than $1.5 \%$ higher than the average of the three best-performing States of the EU, not 2 or 5\%; unsurprisingly, the parameter for interest rates is built in the same way.

As the Maastricht criteria show, the benchmark view of inflation is compatible with fixed rules. Indeed, as these rules would be built taking into account a specific situation, not based on a hypothetical, they would be more practical as they allow for distinguishing between a general cause of inflation (for instance, the oil shock) and a specific national cause (just like this is the case for “alpha” and "beta” in the capital asset pricing model [CAPM]), thus allowing fair comparisons

\footnotetext{
${ }^{5}$ See: https://www.ecb.europa.eu/mopo/strategy/pricestab/html/index.en.html.
} 
between central banks. Therefore, it is somewhat puzzling, prima facie, that fixed rules are never coupled with the benchmark view of inflation. The problem is that if there is no such thing as an absolute "low" inflation, this absolute cannot be the target of economic policy and inflation becomes a means to an end (for instance, a different income distribution or better competitiveness of national firms). In other words, accepting the benchmark theory of inflation means denying the QTM.

In this alternative framework, the relationship between inflation and unemployment is also different. To understand this, we should start from the classical idea that unemployment is a way to reduce wages. Normally, higher unemployment does the trick and workers accept lower wages and worse conditions. But what if unemployment is not able to subdue the labor force? In 1956, the then-Governor of the Bank of Italy Donato Menichella observed:

\begin{abstract}
It is often argued, moreover, and in perhaps too dogmatic or categorical terms, that at a time of full employment it is sufficient for monetary policy to bring about a little unemployment in order to check an incipient inflationary movement [...]. The problem must moreover always be considered in the light of individual circumstances, and of phenomena which may vary, in nature and intensity, as between different times and places. In particular, it must be borne in mind that trade-union policy sometimes tends to overlook the question of the level of employment. (Ciocca 1987)
\end{abstract}

Here it is well explained that the link between inflation and unemployment is not mechanical, and cannot be enclosed by an equation. Just like the gold standard, it is a social convention based on given political and institutional assumptions. If the political balance of forces changes, the Phillips curve changes as well. This was clear to Keynes and even to Marx and Ricardo long before the time inconsistency debate. When unemployment does not work as a threat, inflation can help to regain profitability, as Keynes suggested in the General Theory. In this scenario, inflation is created as a (planned or unplanned) consequence of social and political conflicts, not because central banks produced too much money; this is the effect, not the cause. The Weimar Republic hyperinflation is the quintessential outcome of such social and political conflicts. In calmer situations, inflation is used to prevent income redistribution, as Desai (1973) pointed out: “Inflation is a way of redistributing income away from labor unless labor changes its bargaining strategy to take account of this.” Central banks are inside this process because they strongly influence it (Musella 1988). This influence affects income distribution via unemployment and inflation. As for unemployment, central banks can move interest rates to produce unemployment to exert downward pressures on 
wages (Lunghini 1995). This should prevent income redistribution. When this measure does not work, inflation can reduce real wages, offsetting income distribution changes. In this framework, inflation stems from a distributional conflict that the State is no longer able to control via fiscal policy. Therefore, monetary policy is concerned with income distribution between labor and capital because central banks must assure stability and, as Minsky (1986b) pointed out: “The critical task of stabilization policy is to prevent sharp decreases in profits.”

Here we see the deepest meaning of inflation as a benchmark. In this theoretical framework, inflation is instrumental to income distribution, not a goal per se. The wide debate on the central bank’s objective function acquires a different meaning with this different way of looking at inflation.

\section{RULES AND CENTRAL BANK INDEPENDENCE}

We have seen that, since its inception, the thought behind the advantages of rules on discretion is the central banks are prevented from interfering with the natural (and efficient) dynamic of the economy. Although, at least since Ricardo, the case for rules has been made by many of the most prominent economists of every epoch, they never succeeded. Even in the 1990s, where the victory of laissez-faire policies was overwhelming it happened that "the last quarter of a century has been characterized by a marked trend towards greater discretion in the setting of monetary policy instruments” (Cottarelli and Giannini 1997). The reason why, although rule-based policies have been theoretically successful, central banks have always retained their discretion is that the economy is inherently unstable. This is especially true for financial markets. A striking confirmation of this truth is the permanent illusion of the disintermediation promise (Marotta and Pittaluga 1993). If a set of rules existed for central banking, there could also be a set of rules for banking in general, but if it was possible to reduce banking activity to a set of rules able to connect the present with the future (deterministically or stochastically), banks could be substituted by securities traded on markets and their role could be reduced, at the very best, to rating agencies. Recent history confirmed that banks are not fading away. On the contrary, their importance has never been greater. The disintermediation mantra was never so far away from reality.

In the mainstream framework, the economy is inherently stable and inflation is due to central banks activism. However, as the structural discretion of banking and central banking activity makes rules 
ineffective for taming inflation, the other tool to this end is central bank independence (CBI). The idea is that a more independent central banker is less prone to the Phillips curve trick than the government, as they do not face reelection. Now, literature about CBI is huge, although its conclusions were far from being empirically unassailable, even in the 1990s (for instance Bleaney [1996] and Mangano [1998]). In the mainstream framework, rules and CBI are useful tools against the threat of fiscal dominance, thus accepting a suboptimal Nash equilibrium as the result of uncoordinated policies among the authorities. In the alternative framework the point is, again, the conventional nature of the institutional efficiency of the framework. CBI is effective as far as the general situation allows it. A central bank cannot decide its stance on monetary policy without taking into account its overall implication. Again, it is useful to quote from a former governor: "We asked ourselves whether the Bank of Italy should have refused to refinance public sector deficit [...] it would have had the appearance of a monetary policy decision; in reality it would amount to a seditious act that would provoke State paralysis” (Carli 1975; our translation).

Central banks were created to help the State in financing themselves and they retain this role in every circumstance. If rules or CBI cannot change the balance of forces in society, fiscal dominance is better than State bankruptcy. At least, this is what every central banker has believed so far.

The discussion about fiscal dominance had a significant development because of the crisis. In fact, Carli's bitter observation might well have been shared by many governors after 2008, where the very foundations of CBI were savaged. This is for two reasons. Firstly, the public debt trajectory is out of control. As Cecchetti, Mohanty, and Zampolli (2010) remind us: "Since the start of the financial crisis, industrial country public debt levels have increased dramatically. And they are set to continue rising for the foreseeable future.” Needless to say, without central bank intervention, this would set a trend towards higher risk premia with a growing cost for the State and, in the end, an almost inevitable default. Secondly, but in reality connected to the first point, private debt is also on the rise, therefore overall financial leverage is high and increasing. The process was under way also before the crisis and it is linked to public policies, in particular the deregulation of financial systems and the decline in interest rates (Debelle 2004). As a strong deleveraging would spell disaster for the world economy, the only way out is to maintain the total leverage, increasing its State component, while allowing private operators to deleverage. Once again, this means fiscal dominance, although of a different kind. 
The higher the leverage, the higher the sensitivity of the public and private sectors alike to movements in interest rates and thus the more fragile the situation. Before the crisis, central banks (especially the Fed) had been criticized for keeping the rates too low. Of course, Greenspan also did it because, as he confessed afterwards, he believed in free-market recipes. But more importantly, central banks did it because they had no choice. This is even truer now. The critiques of fiscal dominance (Bayoumi et al. 2014) are tantamount to the idea that central banks can forget the \$58 trillion in public debt and the $\$ 200$ trillion in total debt when deciding their policies. ${ }^{6}$

The degree of independence of central banks marginally has to do with statutory provisions and the conservativeness of central bankers but it is heavily linked to the level of financial fragility of the economy. In the "new normal” (as the IMF calls the present environment for monetary and fiscal policy), the leverage ratio is so high that monetary policy has lost any independence whatsoever in the institutional setup of central banking. All the sophisticated analyses on how to give the maximum efficacy to monetary policy via the perfect set of rules or the maximum independence to the governors can be left to the historians. The point is how to avoid a new financial meltdown.

\section{THE WORLD OF BARRO-RICARDO EQUIVALENCE (BRE) AND THE NATURE OF DEBT}

According to the BRE, an increase in public deficit today, whatever its origin (money or loans), requires higher taxation in the future. As this fact is predicted by taxpayers, they will spend less to be ready when taxes will rise, therefore net private wealth remains unchanged and the stimulus effect of the expansionary policy is neutralized. Thus, the BRE predicts a crowding-out effect that makes fiscal stimulus ineffective and dangerous to financial markets (Barro 2007; Tatom 2009; Forster 2009). Moreover, in the BRE world, wealth effects of public policies are irrelevant so that all public policies of the same amount have basically the same effects (Arestis and Sawyer 2003, 2004).

All these conclusions rest on the specific assumptions on which the BRE is based (Buiter 1979). In particular, we must assume QTM (that also implies full employment), and hence by definition any public policy, makes no sense if we reject the idea that monetary policy is irrelevant to economic

\footnotetext{
${ }^{6}$ Figures from Dobbs et al (2015).
} 
growth; as money is not a veil, fiscal policies can be well coordinated with monetary stimulus (Tcherneva 2008). Secondly, if we reject the representative agent hypothesis, specific policies can help specific sectors of the population. For example, a policy of reducing the tax burden on wealthy individuals, to be financed through the issuing of public debt that will be held by the central bank, implies wealth concentration and not a strong push to demand, due to the different propensity to consume of rich and poor people (Koo 2008). Another example is the huge wealth effect linked to unconventional monetary policies such as quantitative easings (Dobbs et al. 2013).

At any rate, apart from these two hypotheses, there is an even-more striking feature of the BRE: public and private debts are treated differently. In fact, consumers are so smart that they predict new taxes due to, say, an increase in public pensions but not for an increase in big banks' leverage, although they will be called to pay for both but will only benefit from the first. Let's see a tale of two countries.

\section{Box 1. A comparison between country A(lternative) and country B(arro- Ricardo)}

In country $\mathrm{A}$, the government issues $\$ 50$ billion in project bonds to modernize ports and roads so that the transport network becomes more efficient. In country $\mathrm{B}$, big banks buy $\$ 50$ billion in very risky assets. If the BRE holds, taxpayers of country A expect to pay more taxes in the future, taxpayers of country B do not. This is true even if the $\$ 50$ billion comes in both cases from the central bank. Let's suppose that in country $\mathrm{A}$, the central bank lends $\$ 50$ billion to the government buying the project bonds while in country B it lends $\$ 50$ billion to fund the banks. Although similar, still in the BRE world, taxpayers of country A will start to save more for the future, while taxpayers in country B will not.

However, after 2008, can we believe that the general economic efficiency of the country would be raised if banks buy more dodgy debts while it will decrease if the State builds new infrastructure? Critics of the BRE also explained that the equivalence can easily be turned on its head. If public bonds are not net wealth, then "there can be no burden on society as a whole as a consequence of the interest payments that have to be made. While it is true that choosing among taxes, borrowing, and printing money will have distributional effects” (Colander 1997). So the only issue is that more public debt can redistribute income and wealth. Dimensionally, the problem is just not there, as Lerner (1943) observed: “The greater the national debt the greater is the quantity of private wealth. The reason for this is simply that for every dollar of debt owed by the government there is a private creditor who owns the government obligations [...]" We think the crisis has shown that the nature 
of debt during the crisis (public or private) does not matter while the leverage (i.e., the financial fragility) of the economy, does.

\section{THE DEBT DEFLATION PROCESS AND MICROFOUNDATIONS}

Ben Bernanke (1995), in a major analysis of the Great Depression of the 1930s, wrote that "to understand the Great Depression is the Holy Grail of macroeconomics" but "we do not yet have our hands on the Grail by any means.” A number of different explanations have been put forward but, as argued by Bernanke, the problem of prolonged deflationary crises "remains a fascinating intellectual challenge” (Koo 2008). De Grauwe (2009) identifies four deflationary trends: Keynesian savings paradox; Fisher's debt deflation; cost cutting deflation; and bank credit deflation. Although different (the first and the third trends concern flow adjustments like saving and profit, the other two are stock deflations) they interact, creating a prolonged slump.

The core issue in debt deflation is the following: markets are prone to panics and euphoria due to a rapid and collective switch in the expectations of market participants (the "beauty contest" proposed by Keynes and discussed, among many, by Akerlof and Shiller [2009]). Moreover, flow and stock deflations reinforce each other, especially when leverage is increasing, because it ensures financial instability and prevents the balancing mechanisms that normally come into play during recessions for acting. This is also true when the economy faces balance-sheet recessions that produce a dramatic drop in tax revenue and a strong increase in the public expenses (Koo 2008).

As the prisoner's dilemma metaphor aptly shows, there are no viable private solutions to the problem. This should yield, as a theoretical consequence of how markets work, a rethinking of the role of microfoundations. This is especially important inasmuch as this role was used to discredit alternative approaches because, as Colander (2003) pointed out, the acceptance of the need for microfoundations "undermined many of the Keynesian models as being without microfoundations." The theoretical stagnation of the general economic equilibrium (GEE) paradigm and the uselessness of its assumptions to explain the crisis are sufficient, to us, to consider the quest for microfoundations futile vis à vis the quest for a viable explanation of economic cycles. Due to the beauty-contest mechanism, general market trends dominate individual behavior and conventions are the real rational expectations. Even in the best possible situation for mainstream economics, where 
“all agents know each other's aims and anticipate each other's action” (Buiter 1979), the outcome can still be a crisis due to the prisoner's dilemma mechanism (or as the classical economists would have put it, individual profit maximization). The beauty contest mechanism explains why microfounded recipes to avoid or overcome the crisis are weak. In 2008, like in the 1930s, the solution to the debt deflation spiral has been found in the role of the State (De Grauwe 2009). FF already included the rejection of microfounded theories and public finance orthodoxy, as Colander (2003) observed: “In proposing these rules of functional finance Lerner’s purpose was to shift thinking about government finance from principles of sound finance that make sense for individuals—-such as a balanced budget — to sound finance principles (now designated as functional finance) that make sense for the aggregate economy in which government spending and taxing decisions affect levels of economic activity.”

The economic principles used to explain the budget constraints of an individual (i.e., the microfoundations) are as useful for explaining the role of public finances as a brain tomography is for understanding the political ideas of someone. Economics is trying to find a way to acknowledge this (see for instance, Farmer and Foley [2009]).

\section{THE THEORETICAL FRAMEWORK OF FUNCTIONAL FINANCE: RELEVANT AND IRRELEVANT OBJECTIONS}

We have tried to explain why we think the dynamics of inflation, central bank independence, and debt cannot find a proper explanation in the mainstream paradigm while in the FF approach they can.

Functional finance proposes a theoretical framework (Lerner 1943; Wray 2003, 2009a, 2009b) that rejects the concept of "sound public finance" in favor of the full utilization of economic resources. Lerner (1943) wrote: “The first financial responsibility of the government (since nobody else can undertake that responsibility) is to keep the total rate of spending in the country on goods and services neither greater nor less than that rate which at the current prices would buy all the goods that it is possible to produce” (see also Arestis and Sawyer [2003]).

The logic is quite different from the orthodoxy. Full capacity (including full employment) is the ultimate goal for government and central banks. As QTM does not hold, and the system is 
intrinsically unstable, there are no alternatives to public intervention. In light of these completely different assumptions we can re-read the main issues mentioned so far: inflation, BRE, and CBI.

As we have seen, in this conceptual framework inflation is basically the outcome of a mismatch between what the State can actually do and what it is supposed to do in term of services, income redistribution, and so on. The mismatch can take the form of inflation or public debt increase. In both cases there is a question of sustainability that leads us to go back to the main issue-public versus overall debt.

The first point is dimensional: the debt-to-GDP ratio is historically increasing and it is now at record levels on a world scale (Dobbs et al. 2015). ${ }^{7}$ Does mainstream economics have any viable explanation for this trend? If this is the case, how can it give practical suggestions on how to handle something that it cannot explain? Orthodoxy is also unable to explain why, notwithstanding the hard battle fought under the banner of Thatcher-Reagan-Laffer et al., the State economic retrenchment never materialized. We think alternative theories able to deal with these aspects should be taken into account. This is especially true when considering a specific number as a trigger event to a crisis like the famous $90 \%$ figure by Reinhart and Rogoff. ${ }^{8}$ Besides those, functional finance implicitly develops another kind of criticism. Lerner wrote in 1943: “As long as the public is willing to keep on lending to the government there is no difficulty, no matter how many zeros are added to the national debt." The willingness of the public is based on the relative riskiness of the different asset classes. Investors can accept buying a sovereign bond of a country with $100 \%$ debtto-GDP ratio if the average world ratio is, say $110 \%$, less so if the latter is $60 \%$. Given that high public debt is the new normal and the financial markets know it, functional finance seems a better theoretical framework to assess the soundness of public finance.

The second point we already raised is the composition of debt. In the BRE-Maastricht world, ${ }^{9}$ debt is not all created equal. However, the crises of the last twenty years have demonstrated that private debt matters, not only public debt. So every discussion about the sustainability of public finance should take into account the situation of total debt, not only of public debt. Returning to our comparison, let's give an example:

\footnotetext{
${ }^{7}$ In the following discussion, percentages represent a proportion of GDP.

${ }^{8}$ See, for a critique of their work, Herndon, Ash, and Pollin (2013).

${ }^{9}$ We use the Maastricht Treaty conditions as the quintessence of BRE and orthodox theories in general put into an institutional arrangement.
} 


\section{Box 2 . A new comparison between country A(lternative) and country B(arro-Ricardo)}

Country A has $70 \%$ public debt and $150 \%$ overall debt. Country B has 59\% public debt and 300\% overall debt. According to BRE-Maastricht Treaty criteria, country B is in better shape than country A. However, what happens if a crisis strikes the banking system of the two countries? The States are forced to intervene and the resources they will mobilize depend on the dimension of the financial system (i.e., the overall leverage).

This happened after 2008, when the States (via fiscal and monetary policy) increased their debt enormously to save the banking system. Take the case of Ireland. Between 2008 and 2012, Ireland registered a huge public deficit to save its banks. As a consequence, while in 2007 public debt was below 25\%, in 2012 it was more than 111\%—a resounding demonstration that private and public debts are connected. If consumers, besides the government's budget constraint, also internalize the growth of private debt because the State will be forced to rescue too-leveraged banks, what happens to the BRE?

If the BRE should be completely rethought on a dimensional plane, it also needs to take into account a composition aspect. State intervention means many different things and although its overall weight on the economy is not changed too much, the specific interventions did change, as Minsky already pointed out long in advance (see, for instance, Minsky [1986a]). Nowadays, public expenditures no longer reduce inequality or they do it a lot less than before (OECD 2014), especially if we take into account the economic role of the State as a whole (i.e., the interests paid on the public debt, the purchase of products and services from the private sector, and so on). The change in the composition of State expenses is irrelevant in the context of mainstream BREMaastricht consensus, but its consequences on economic growth and income distribution are important (as Lerner already suggested), hence its impact on financial stability, something that is now even too obvious: when wages do not cope with economic growth, financial leverage goes up, pushing the world into a Ponzi position. In the context of high leverage, warnings about FF as a threat to "sound finance" make no sense. In fact, in the FF approach an increase/decrease of public debt is good or bad if it is able to improve the overall macroeconomic conditions of a country. This is the necessary starting point for debating public debt and deficit today.

In doing this, the FF approach can help to reverse the long-term regression of fiscal policy in favor of monetary policy (Casadio, Paradiso, and Sarcinelli 2009). As the dominance of monetary policy produced a colossal growth of the financial system across the world economy and a record income 
and wealth inequality, the return to fiscal policies (including a new relationship between the government and the central bank) can help financial stability. Therefore, let's see how to reply to the critiques of FF.

A first critique is based on the supposed allocative distortions produced by public debt. As we noted, this is a truism inasmuch as it is based on the hypothesis that the economy is already running at its best (after all, if ain’t broken don't fix it). As in the real world, the economy breaks all too often; this danger is not material. What is at stake is the following: Is public debt able to put economy back on its feet? If this is the case, confidence will raise and private investment will increase. The private or public nature of the investment is not so important. If Airport Enterprises, Ltd. issues $\$ 5$ billion to renew its infrastructure, are the consequences on the economy different whether it is listed on the stock exchange or it is owned by the State? We think the crisis has demonstrated that debts are debts. Private investment is not low because of the BRE, but because private investors predict low growth for long time. This is due to inequality and low wages, not to public intervention, and austerity is only worsening the situation. However, we must also be reminded that by the same token, the unprecedented lowering of interest rates cannot prop up private investment alone. To give an example, when the world car industry's excess capacity is in the range of 30 million units out of a capacity of 90 million, what is the point in investing to create new car factories, even if interests rate are negative?

The second aspect is that public borrowing is accused of having adverse effects on the markets, including labor and financial markets (Greenspan 2009). These conclusions should be connected with the situation before the crisis, which witnessed a record increase in income and wealth inequality, and the victory of laissez-faire policies in labor as well as in financial markets (Kumhof and Rancière 2010). That Greenspan believed it comes as no surprise. After all he said (2007, 231): "I would tell audiences that we were facing not a bubble but a froth-lots of small, local bubbles that never grew to a scale that could threaten the health of the overall economy.” This is the laissezfaire prescience that pushed central banks to scrutinize State expenses for troubles to come while ignoring the build-up of a colossal Ponzi scheme in the private financial markets. Now we can see which was the strongest danger for world economy. Public borrowing did not have adverse effects on the markets but the other way round. 
A third point is that fiscal dominance can yield inflation. Now, inflation is nowhere to be seen. QTM supporters explain that inflation will materialize "at a later stage.” This is not particularly useful though. To paraphrase an old aphorism, even a mistaken theory is right twice a century.

If the objections above do not seem relevant for the present situation, we think there are two others that are. The first is connected to the link between the State and financial markets. Different public debt dynamics can have strong effects on capital flows even without currency risk, as the euro area sovereign spreads have shown. The pressures exerted by market conditions have been able to topple governments. Sometimes this problem is linked to the "novelty" of globalization. But this is nothing really new. For instance Bagehot, writing in 1873, exposed the same problem and suggested increasing the interest rate "to counter the foreign drain" (Ciocca 1987); Ricardo made similar remarks much earlier. More than the public-debt-to-GDP ratio per se, what is relevant is the quota of foreign-owned public debt. This explains how it is possible for Japan to safely sustain a 250\% ratio, while other countries were destroyed by financial speculation with a much lower ratio. This aspect should calm the most extreme supporters of the modern monetary theory (MMT). As Aspromourgos (2014) explains: "Public debt which is either foreign-owned (especially if foreigncurrency-denominated), or a potential liability to make payment in something else other than fiat domestic currency (notably, a gold-convertible domestic currency), raises additional difficulties and constraints, primarily because involving assets that government cannot freely create ex nihilo.” For the euro area, which has a single central bank but dozens of sovereign issuers, many have proposed a mechanism of mutualization to reach a situation more akin to Japan, but to no avail so far (Varoufakis 2014). After the crisis, economists should also investigate if the completely free circulation of capital with its consequences of financial deregulation, off-shore centers, the rise in money laundering, and so on is something that really benefits the world economy.

Secondly, there is an issue of accountability and transparency in public expenditures ("value for money”). The southern countries of the euro area are often accused of corruption and insufficient efficiency of their public administration. This was part of an all-out ideological battle against everything public, a battle to help firms’ profitability via deregulation, privatization, and so on. However, we should keep the baby while throwing the bath water away. An efficient use of public money in a time of high public debt is more important than ever. And the FF approach must take this issue into account as we will see. 
Finally, as far as CBI is concerned, we have explained why the growth of the financial system and of the overall leverage has stripped the central banks of any real independence. But there is a different meaning of independence that has emerged during the crisis. Central banks decided to dismiss mainstream wisdom and save the world. They were discretionary, unpredictable, and heterodox to the extreme. They showed a remarkable independence-not from the government but from wrong theories. They ended up with an expanded function in the economy as lenders/investors of last resort (roughly doubling their assets since the start of the crisis) and in other roles. The events during and after the crisis were a remarkable confirmation that rules cannot help. The world economy cannot simply be fit into them.

The crisis also confirms that every aspect of the economy - the conduct of monetary policy, the institutional design of central banking, the role of public and private debt, the nature of inflation-is interconnected and linked to the more basic issue: the nature of money. That is why an alternative approach can help on all these matters.

\section{PUBLIC FINANCE AND ECONOMIC STABILIZATION: A PRAGMATIC APPROACH}

The discussion about the effectiveness of countercyclical measures is normally limited to the analysis of a single country. However, the situation of a generalized crisis of the world economy is different and the fragility more lasting (Spilimbergo et al. 2009). This brings us back to the inability of a micro-based theory to analyze the present situation. Whereas a specific measure is suitable to help a single country to escape recession, the same policy cannot help when the weakness is generalized. A glaring example is the export-led recovery strategy that is, by definition, not feasible worldwide. The same is true for austerity that can help the public finances of a single country but when used by every nation is counterproductive. What counts in this situation is not so much the quantitative direct effect of the single measure but its capacity to reduce uncertainty and instability - the signaling effect. Therefore, when we consider the efficacy of a specific measure, fiscal and monetary policy alike, we must start from this aspect: its practical effectiveness when used on a worldwide scale.

FF can help in this context, for two main reasons. First of all, it does not consider public finance as if it were the finance of a single private agent and underlines the overall effects of expansionary fiscal policy. Secondly because it is basically a "whatever-it-takes" approach ante litteram, that sets 
aside the "traditional doctrine about what is sound or unsound" (Lerner 1943). FF has been traditionally criticized for its alleged indeterminacy and discretionality in terms of targets and timeliness. We explained why, after Lerner, the theory has favored fixed rules (in fiscal as well as monetary policy); this is also because rules are more accountable and transparent (Balassone and Franco 2004). However, in a structurally uncertain environment such as the post-crisis world economy, flexibility is preferable to fixed parameters. As for “credibility” and "reputation,” we think that a government or a central bank that, sticking to the rules, allows an economic meltdown will not retain much credibility and reputation, while a "whatever-it-takes" approach, although difficult to translate into fixed rules, if effective, will raise them. We should only add the need of an accurate coordination of expansionary policies to ensure their maximum efficacy.

If the need of a generalized fiscal expansion is now easier to accept due to the inability of conventional and unconventional monetary policies to revamp the economy, the concrete measures can vary. The FF approach is based on public investment because it has two positive features: it reduces the overall production costs, both directly and indirectly, and it increases productivity (see the reading of Lerner proposed by Forstater [2003]). Above all, public investment creates most new economic sectors from scratch, whereas private investment intervenes only after they are already established, for obvious uncertainty reasons (Mazzucato 2013). In other words, public investment in innovation is by far more productive than private investment.

Of course, public investment increases productivity when it is carefully selected. As for the dimension of these projects, they should be assessed analyzing the general budget of the Stateconsumption and investment—and an appropriate financial balance between the two components should be established (Balassone and Franco 2004). If we accept that in the medium to long run, public investment is more than self-repaying, constraints to the expansion of State investment are only represented by the need to maintain stability in terms of inflation and debt markets (Aschauer 1998), but this is also true for private investment, as recent history has painfully taught.

Secondly, public investment increases income and wealth equality, as they benefit most or all citizens. This is a decisive step in helping economic growth, but to tackle inequality that is detrimental to growth and productivity other measures are needed, such as a wage policy able to avoid strong changes in income quotas and rigorous taxation on income and wealth. It is true that these Keynesian recipes are more difficult to realize in a globalized world. However, when the 
States were forced to save the banking system, they did it, notwithstanding the globalized nature of the banking activity. The question is the political willingness to intervene.

These aspects are important, but there is an even more important characteristic of public investment: its coordination-confidence restoring role. In the banking system, this role is played by lending of last resort. As financial markets are based on the logic of the prisoner's dilemma/beauty contest, public intervention represents an irreplaceable signal of confidence. This is an old idea that goes back at least to Bagehot. Lending of last resort is the only way to convince markets that the State is behind the banking system whatever the troubles will be, so that investors keep or regain their temper. FF has basically the same role for the economy as a whole. Just like it would be pointless to underline that emergency lending by central banks crowds out private funding (the latter is simply not there), the crowding-out effect works very differently from how the BRE predicts also in fiscal matters. If the State does not restore the market's confidence, investment will first collapse and then stay low. It is State passivity that crowds out private investors. Without public intervention, uncertainty cannot be dissolved and uncertainty produces a collapse of private investment. In general, if QTM does not hold, private investment increases when overall demand is increasing.

\section{FUNCTIONAL FINANCE IN THE TWENTY-FIRST CENTURY}

The FF approach suggests a new way to assess the degree of freedom enjoyed by a State balancing its economic intervention with its resources (Bell 1999; Nell and Forstater 2002; Forstater 2003). First of all, the FF approach rejects the idea that a balanced budget is intrinsically good whatever its impact on the economy (Seccareccia 2010a, 2010b). In fact, the fiscal choices made by many governments after 2008 show that the mainstream consensus was based on very hollow assumptions. However, interventions are not all the same. They can target specific sectors of the population and can have different timing if political conflicts delay their adoption (Alesina, Ardagna, and Trebbi 2006). Political consensus is particularly important today, because stabilization policies were very costly and much of the population has been damaged by the crisis directly (because of unemployment, wage cuts, and so on) and indirectly when they were called to pay for the stabilization policies. As pointed out by Taccone (2008), a government needs accurate and shared criteria for economic compensation, so that the different categories of public expenditure can be prioritized according to widely shared principles. 
FF takes into account these considerations as well as the lack of credible criteria to determine the sustainability of public debt (Pasinetti 1998). The FF focus is always on economic growth: can deficit spending, with the specific measures taken by the government, raise growth and productivity? Cutting State resources during a slump does not reduce debt, as the case of Greece shows conclusively. A famous aphorism by Keynes sums this up brilliantly: "Look after employment and the budget will look after itself” (quoted in Garside [1990]). On the other hand, a continuous expansion of the debt is not efficient. But again, this is not true only for public debt but for debt as a whole, because when the leverage increases too much, financial markets are ruled by (mostly involuntary) Ponzi schemes, forcing the State to bail them out. When debt-to-income (or debt-to-GDP) is so high, it cannot be repaid. As is very often the case, the classics knew better. Adam Smith (1776 [2007], 725-26) explains:

\begin{abstract}
When national debts have once been accumulated to a certain degree, there is scarce, I believe, a single instance of their having been fairly and completely paid. The liberation of the public revenue, if it has ever been brought about at all, has always been brought about by a bankruptcy; sometimes by an avowed one, though frequently by a pretended payment. The raising of the denomination of the coin has been the most usual expedient by which a real public bankruptcy has been disguised under the appearance of a pretended payment.
\end{abstract}

In the euro area, where the national States cannot print money, the only solution left is a de facto or formal debt consolidation (Forges Davanzati 2009). If we exclude ways to bypass austerity using, for instance, a complementary currency, the loss of monetary policy flexibility adds a limit to the other mechanisms the States already have (trade balance, credibility on the international markets, and so on). For this reason the most rigorous theorists of FF are against any form of monetary independence from the State (Nersisyan and Wray 2010). The question is how much a country with a "normal" currency (that is not the US dollar) can withstand the pressures of the markets. This is the independence that matters. All in all, it is crucial in this situation that the FF approach comes with a set of principles able to guide government actions over time. True, there is no guarantee that State expenditure will be effective in leading to economic development, but this is also the case with private investment. What is needed is a structured management of public finances to foster concrete policies suitable for changing course. 
Traditionally, FF has been described as obeying the following principles (as redrafted by Colander [2003]): ${ }^{10}$

1) The State must keep a reasonable level of demand in all circumstances. If unemployment is too high, the State should increase expenditure or cut taxes. If, on the other hand, the labor market is so tight that inflation starts to increase, the State should reduce its expenditure or increase taxes. The principle is to use government spending as a stabilizer.

2) Monetary policy should be aimed at creating, using interest rates and its other tools, the level of investment needed to guarantee full employment (Lerner calls these two principles "the first financial responsibility of the government”).

3) Assured the full utilization of resources, the State should pursue a balanced budget, i.e., this objective is subordinate to full employment.

Colander observed that these principles, which enjoyed academic and political success in the 1950s and 60s, proved to be insufficient - in terms of a politically and socially acceptable unemployment and inflation rates - from the mid-1970s onwards. This meant the death knell for FF as a viable theoretical alternative. Starting in the 1980s, universities and authorities were (re)conquered by QTM supporters, with the all-due consequences_-rules rather than activism, inflation is a problem unemployment is not, inequality - that is greed, to quote Gordon Gekko, is good and financial markets are efficient.

The laissez-faire victory also influenced the FF approach: Colander included a fourth principle by which the government should pursue price stabilization policies and coordinate the above principles with the inflation level set by the central bank. At the time, inflation was presented as the biggest economic problem, if not the only economic problem. This has completely changed after the crisis, and in the "new normal” the fourth principle seems largely outmoded. Inflation is not of any concern and the real issue facing States and their central banks is how to combine the set of policies available to overcome the crisis. Therefore, we believe that in the new scenario a "fourth 2.0"

\footnotetext{
${ }^{10}$ Lerner called them laws; the supporters of FF call them rules. However, borrowing from the debate in banking supervision between rule-based supervision and principle-based supervision, we think it is more suitable to call them principles as we are describing a general philosophy of intervention and not a completely worked out measure of intervention. Also Keynes thought that functional finance is an idea and not a policy.
} 
principle can help: the State should implement policies able to boost efficiency and productivity by increasing the nation's human and technological capital.

Our principle should not be read as confined to, for instance, infrastructure. A more efficient public administration or better universities also enhance productivity. Public investment efficiency should be judged by this very broad meaning. This principle is complementary to the first three: public investment should be conducted in the framework of the full utilization of economic resources, especially full employment, so that distributive justice and resource allocation help each other (Musgrave 1959).

With the crisis, the horizon of public policies is getting shorter because a very frustrated electorate tends to change party en masse, so that government is not interested in long-term strategies but only in their immediate survival. This trend worsens the situation as public money is not used to permanently strengthen the economy. Therefore our fourth principle is more important than ever. We will try to show how to transform these principles in specific policies.

\section{THE “HOW TO DO” LIST}

In a celebrated comical sketch an Italian comedian, impersonating a famous entrepreneur, is lecturing the nation on how to revamp the economy when, asked about how to do it specifically, he apologizes that he has lost the "how to do" list. Even if the FF approach is above all a general idea, we will try not to follow the same path. In particular, we will touch on three points: dimension, composition-sequence, and accountability of public intervention.

The first point is connected to the laws posed by Lerner as the essence of FF ("the first financial responsibility of the government”). Basically, this dimension is connected to full employment. It can be argued that the FF approach implicitly entails an active policy to reach full employment like, for instance, the "employment of last resort” program proposed by Minsky (see Mastromatteo and Esposito [2014] on the issue). As long as there are unemployed workers, public intervention is not enough.

The second point is more complex. Is there a better menu of interventions in terms of investmentconsumption mix, sectoral investment, a specific sequence of public policies, and so on? Traditional 
wisdom states that the government cannot know better, so it's better to simply give out money (normally in the form of tax rebates) and let the people decide how to spend it. However, confronted with serious difficulties, governments and central banks have renounced traditional wisdom. When the banking system collapsed with Lehman Brothers, no one proposed to give any citizen, say, $\$ 30,000$ to spend as they wished. All the efforts were concentrated on bailing out the banks. In other words - when the going gets tough, the State knows better. We also think this is the case for economic growth. Generally speaking the intervention of the State should be aimed at pushing for a fairer income and wealth distribution, which is also conducive to higher economic growth. For scale and scope of economies reasons, we think this intervention is better made in kind rather than giving monetary subsidies. For instance, the State can build kindergartens or can give every family with a toddler a tax rebate. We prefer the first option because it is more productive. At present, the bulk of domestic work is done by women for free with very low productivity; socialization would enormously increase overall productivity, reducing the costs of reproduction of the labor force. It is not by chance that the northern States, like Scandinavia, where more domestic work is socialized, the labor force is more productive and more women enter the labor market.

As for investment, we also prefer a direct intervention to tax rebates because of uncertainty. The future is uncertain, and private investors are frightened by uncertainty, which only the State can dissipate. This is one of the main arguments in favor of an active employment policy, as Lerner (1943) observed: "since one of the greatest deterrents to private investment is the fear that the depression will come before the investment has paid for itself, the guarantee of permanent full employment will make private investment much more attractive.” Moreover, full employment forces firms to rely on innovation to compete and not on cutting wages. We have known this at least since Ricardo. That is why the most innovative countries are the ones with the highest wages. This shows that the dimensional aspect is also linked to a composition effect. If the public intervention is big enough it also has the strength to start private initiatives, but the primum movens is the State.

The same idea of an industrial policy is anathema for orthodox economics and yet the reality on the ground is that no private investor can afford the deep and overwhelming uncertainty that surrounds a breakthrough innovation, something that changes the social and economic landscape, like internet did. Even venture capitalists start to finance a sector when the outcome (in terms of profits) is four to five years away. In fact, almost any major technological breakthrough is based on massive State investment (Mazzucato 2013). This is obvious because we are talking about projects that will start to yield profits after years or even decades. Therefore, as the direct and indirect intervention of the 
State in industrial R\&D has been falling for years, sweeping technological advancements are lagging.

Uncertainty is the main reason why basic infrastructures (including what was needed for the information and communications technology revolution) were built by public investment, although sometimes they are now in private hands. Uncertainty is also linked to the issue of different technical standards. The State chooses a standard so that private firms and investors can focus on it avoid the wasting of resources. This is also efficient because the victory of a privately chosen standard is a painful and costly process and does not ensure an optimal outcome but only the survival of the strongest and most ruthless alliance behind the winning standard (for instance, Katz and Shapiro [1985]). This alliance tends to suffocate any alternative, albeit technologically superior, for the so-called “dominance design effect” (Suarez and Utterback 1995).

The role of the State should be concentrated in long-term investment able to increase total productivity. This means, above all, infrastructure and collective services. We are talking about, broadly speaking, pure or quasi-pure public goods, marginally produced by the private sector. Even when there are privately owned firms that offer them, they never target the whole market; on the contrary they discriminate (market skimming) leaving the State to serve the most problematic and costly clients. This is also the reason why private firms are often "more efficient": they simply choose the most profitable customers. This is the case, for instance, with public transportation or healthcare. Needless to say, this kind of cherry picking exacerbates social inequality. In many cases, there is also an issue of fraud and regulatory capture (Enron and the banking sector are among the most striking examples of both). On the contrary, full employment policies and public investment increase fairness and equality. This helps economic growth in many different ways. This is especially true for debt: good and stable wages reduce financial leverage so that the State will save enormous amount of money at a later stage.

The third point is accountability. This is strictly linked to the first two issues. In fact, we have a dimensional accountability and a compositional accountability. The first kind of accountability is based on the first three principles, the second kind on the fourth. Overall they are what is needed to assure that FF principles are used for good.

Dimensional accountability is linked to financial prudence. Here we have different opinions even among State interventionists. For instance, Minsky, who never held back from criticizing laissez- 
faire policies, stressed the importance of a public sector with a solid financial structure, as part of a robust financial structure of the economy (Minsky 1986a). This prudence is not shared by the most ardent FF supporters, who underline that it would be in conflict with Lerner's third law, which asserts the priority of economic (monetary and fiscal) policy over the objectives of sound finance. Furthermore, according to the more radical Chartalist interpretations (Wray 2003, 2009c), limits on the public budget are artificial as long as a State can print money. In this approach, the State is not bound by any particular quantitative threshold, unlike private operators, who are restricted by their income. In reality, the long-term historical trend of financial leverage shows that for families and private firms the limit is also very flexible. This flexibility is also possible for public bond issuing. Dimensionally public finances should have the right composition, as Lerner (1943) observed:

\begin{abstract}
If the public becomes reluctant to keep on lending, it must either hoard the money or spend it. If the public hoards, the government can print the money to meet its interest and other obligations, and the only effect is that the public holds government currency instead of government bonds and the government is saved the trouble of making interest payments. If the public spends, this will increase the rate of total spending so that it will not be necessary for the government to borrow for this purpose; and if the rate of spending becomes too great, then is the time to tax to prevent inflation. The proceeds can then be used to pay interest and repay government debt. In every case Functional Finance provides a simple, quasi-automatic response.
\end{abstract}

The generosity needed to keep the financial system afloat after 2008 shows that fiscal prudence is subordinated to a sort of survival test. In the long run we can agree that public finance should be balanced but, again, this makes sense only looking at the whole picture- that is at the financial leverage of the economy.

The second kind of accountability is linked to the control of the State's role in the economy. This is a multi-faceted theme. First of all, there is an issue of transparency towards the citizens. The criteria behind the use of public money should be clear and unambiguous. For instance this means transparent criteria in recruitment, in the priority lists of beneficiaries of public programs, and so on. A clear set of rules is the first necessary step, but it is not much if there is no effective enforcement. Every modern State has some form of the Italian "Corte dei Conti” or the US Government Accountability Office (GAO), a State supervisory body that controls how public money is spent. These structures are vital and they should operate in the most effective way. However, they are not enough. Public projects are a way to give products and services to specific sectors of the population. 
It is important that these programs are not seen as something coming from far away but that are built, implemented, and monitored by the population itself.

Therefore, we think that the government should create a State agency similar to a banking supervisory authority in charge of controlling how public money is spent (let's call it PFS—public finance supervisor). ${ }^{11}$ However in order to effectively monitor how public money is spent, it is mandatory to mobilize the population itself. Only local communities, interested citizens, and so on have the possibility of ensuring that public money goes where it is needed. Therefore, this public body should set up a small local control commission comprised of citizens adequately trained by the PFS, PFS-nominated experts, and representatives of public workers (approximately one-third each, for nine total representatives). This commission should be in charge of verifying the effectiveness of the projects undertaken and could be, in a sense, a local branch of the PFS. The active participation from below and the expertise and coordination from the PFS could ensure that public money was being used efficiently. Every school, every hospital, and every major infrastructure project would have a PFS branch able to control what's happening on the ground. As for the practical toolkit of this supervision, the experience of banking supervision can easily help: on-site inspections, off-site analysis of a structured series of efficiency indicators, analysis of the quality of management, consumer protection tools, and so on. In this context, the PFS local branch would be similar to a resident examiner in the US banking-supervision tradition.

One can think of many other ways to reach the same goal, that is to mobilize the population that enjoys (or suffers from) the output of public finances to monitor their efficacy. Here we have only given some examples to stress the importance of the issue.

\section{CONCLUSIONS AND ISSUES FOR FURTHER RESEARCH: FUNCTIONAL FINANCE AND CONTEMPORARY CAPITALISM}

As reminded euphemistically by Bayoumi et al. (2014): “The global financial crisis challenged the existing monetary policy paradigm.” Indeed, mainstream paradigm as a whole has shown to be useless in understanding, preventing, or curing the crisis. The "new normal” has helped the resurrection of fiscal policy even if we are only at the beginning of a discussion about the scientific viability of different theories. We think the conspicuous task of revamping the world economy

\footnotetext{
${ }^{11}$ For a specific application of this scheme to the employment-of-last-resort project, see Mastromatteo and Esposito (2014).
} 
requires a new approach. The words of Lerner (1943) seem prescient: "to grapple with this problem even if it involves a little careful thinking and even if the thought proves somewhat contrary to our preconceptions.” Quite contrary indeed.

We suggest that developments in the world economy confirm the suggestions made by Lerner and Minsky. As financial leverage is enormous and climbing, no one has a balanced budget anymore, not even over the cycle. Moreover, the longer the period of stability the more destabilizing it is, exactly because it prepares the ground for financial fragility. ${ }^{12}$

This turnaround is somewhat facilitated as conclusions stemming from the traditional wisdom are under review. This is especially true for the relationship between monetary and fiscal policy. Central banks accomplished their duties avoiding the meltdown of the banking system with a whatever-it-takes approach. They cannot do much more apart from helping fiscal policy. It is the turn of fiscal policy to overcome stagnation. Monetary and fiscal policy, as well as the financial regulatory framework, should all have the same objective that can be summarized in the famous Draghi's (2012) dictum: To do whatever it takes to spur long-term economic growth.

After the failure of the mainstream consensus, FF deserves to be deepened as it has a distinctive approach to any major issue on the table. It entails a different relationship between fiscal and monetary policy, the trashing of fixed-rules policies in favor of discretion that is not equal to erratic behavior but means creativity and boldness, overcoming central bank independence, and the BarroRicardo equivalence. The FF approach has been accused of being vague, but vagueness is in re ipsa. Banks, finance, and money are based on confidence and confidence is nothing that can be measured or maintained by adhering to rules. In fact, central banks already renounced rules and embraced the core message of the FF approach. However the overall stance of economic policy is still based on discredited assumptions. It is time to accept in the realm of theory what it is already practiced by public authorities.

In this work we have tried to explain how to develop the FF approach to take into consideration the most important features of world the economy, especially as far as financial stability is concerned. The FF approach is based on a long-term outlook for the economy as a way to overcome short-term problems and short-termism as a political dead end. Public intervention in the economy should pursue the goal of increasing the productivity of the economic system, with a view to achieving

${ }^{12}$ This is now acknowledged even in mainstream models, for instance, Brunnermeier and Sannikov (2014). 
sustainable growth and, over time, allowing the debt to be suitably refinanced, managed, and reduced.

Luckily, the fear of (public) deficit and debt did not stop central banks and government from saving the banks. This is the right approach in general. Too much financial leverage is the most serious threat to long-term growth. What is needed is a macroeconomic strategy able to reduce it. Austerity is not able to do it. In fact, after years of austerity, financial leverage and fragility are more worrisome than before. Only a structural increase in economic growth can do it. We proposed a framework for determining the dimension and the composition of this intervention and how to keep it accountable, taking into account the "new normal" for the world economy and the fact that traditional conclusions about the efficiency of "private solutions," the invisible hand, and so on are, at best, dubious.

We explained why a wide public intervention is mandatory for sustaining economic growth, but we are aware that there is much work to do to give operational suggestions. First of all, it is true that basically every new economic sector after WWII has been created by public investment. However many or most of this investment was connected to the needs of the Cold War. It is not a historical accident that after the demise of the USSR, public investment has declined. Given that no one can hope for a new Cold War, what is at stake is how to create the same sense of total mobilization and deep focalization without risking a thermonuclear Armageddon. President Lyndon B. Johnson proposed a War on Poverty, something that is more relevant than ever. Similarly, we could think about a War on Climate Change to completely reshape the world industrial machine.

The second point is financial leverage. FF explains why State finances are an opportunity for economic growth and not a risk. This has been proved since 2008, but FF must also take into account the fact that leverage is high and increasing. An overall deleveraging can be achieved only with a strong acceleration of growth. For the time being, the only solution is to modify the composition of total debt, increasing the public part to help corporate profitability. This has always been the policy on the ground even during laissez-faire infatuations. The question is that public money has been given without conditions. In fact, the financial behemoths that were saved by taxpayers are still there, bigger and as reckless as before 2008. It is true that banking regulation has been tightened, but the overall weight of big banks has not been touched. In fact, the markets are not impressed by this crackdown, as can be seen in the record level of market indicators. This situation is economically and politically untenable. 
The third point is the future of globalization. The financial collapse of 2008 was a serious setback for globalization, especially because facing huge bills for rescuing the banks, national States started to quarrel about the so-called burden sharing, a situation effectively synthetized in the aphorism by the former BoE Governor King: "that great international banks are global in life, but national in death." 13 The breakdown of international banking has been somewhat stopped by central banks and governments, but the problem is still there. Above all, it is clear that the future of globalization is, more than ever, dependent on political decisions. In this regard, it is clear that much more international coordination is needed. Globalization can survive only if global political governance will work, because, as Turner (2009) noted "the world has a global economy but not a global government.” Now, if we look at the events in Greece, the efficacy of international governance does not seem inspiring. All these issues should be deepened.

And finally, there are theoretical aspects that need to be clarified. FF proposes rebuilding economics starting from macro-dynamics. What kind of theories and models can flow from this general idea is yet to be seen. Moreover, if the role of the State is important, especially because it can dissipate uncertainty and if the political choices are what matter for the future of world economy, what is the point in using econometric techniques to suggest this policy or that? Economics should use other kinds of tools and be closer to other social sciences more accustomed to strategy and politics.

These are all issues that deserve more research. All in all, we believe that this is the right time for reconsidering many policies, whether financial deregulation or the total freedom of financial movement that has proved disastrous even in orthodox narratives. It is the right time for innovative thinking. The practical men that, according to Keynes, are "usually slaves of some defunct economist," have demonstrated remarkable bravery in breaking this slavery. Economics should be restarted from here.

\footnotetext{
${ }^{13}$ As quoted in The Economist (October 12, 2013).
} 


\section{REFERENCES}

Akerlof, G., and R. Shiller. 2009. Animal Spirits: How Human Psychology Drives the Economy and Why It Matters for Global Capitalism. Princeton, NJ: Princeton University Press.

Alesina, A., S. Ardagna, and F. Trebbi. 2006. "Who Adjusts and When? On the Political Economy of Reforms.” NBER Working Paper no. 12049.

Algaze, G. 2006. Ancient Mesopotamia at the Dawn of Civilization. Chicago: University of Chicago Press.

Arestis, P., and M. Sawyer. 2003. “The Case for Fiscal Policy.” Levy Economics Institute of Bard College Working Paper no. 382.

_. 2004. Re-examining Monetary and Fiscal Policies in the Twenty-First Century. Cheltenham: Edward Elgar.

Aschauer, D.A. 1998. “How Big Should the Public Capital Stock Be?” Levy Economics Institute of Bard College Public Policy Brief no. 43-A.

Aspromourgos, T. 2014. “Keynes, Lerner and the Question of Public Debt.” Available at: https://varoufakis.files.wordpress.com/2014/01/ta-on-debt-paper-1.pdf

Balassone, F., and D. Franco. 2004. "EMU Fiscal Rules: A New Answer to an Old Question?” in G. Eusepi and F. Schneider (eds.) Changing Institutions in the European Union, A Public Choice Perspective. Cheltenham: Edward Elgar.

Barro, R.J. 2007. Macroeconomics. A Modern Approach. Mason, OH: South Western College Publishers.

Bayoumi, T., G. Dell’Ariccia, K. Habermeier, T. Mancini-Griffoli, F. Valencia, and an IMF Staff Team. 2014. “Monetary Policy in the New Normal.” IMF Staff Discussion Note no. 14/3.

Bell, S. 1999. “Functional Finance: What, Why, and How?” Levy Economics Institute of Bard College Working Paper n. 287.

Bernanke, B.S. 1995. "The Economics of the Great Depression: A Comparative Approach.” Journal of Money, Credit, and Banking 27(1).

Bleaney, M. 1996. "Central Bank Independence, Wage-Bargaining Structure, and Macroeconomic Performance in OECD Countries.” Oxford Economic Papers 48.

Boffito, C. 1973. Teoria della moneta. Torino: Einaudi.

Brunnermeier, M.K., and Y. Sannikov. 2014. “A Macroeconomic Model with a Financial Sector.” American Economic Review 104(2).

Buiter, W. 1979. “The Macroeconomics of Dr. Pangloss.” Mimeo, Princeton University. 
Carli, G. 1975. Considerazioni finali. Rome: Banca d'Italia. Available at: http://www.bancaditalia.it/chi-siamo/storia/governatori-direttorigenerali/CF_1960_1981.pdf . 1988. Pensieri di un ex governatore. Pordenone: Edizioni Studio Tesi. 1996. Le due anime di Faust. Rome: Laterza.

Casadio, P., A. Paradiso, and M. Sarcinelli. 2009. "La politica economica: quale aiuto allo sviluppo in Italia?” in Economia Italiana 2009/1 and Economia Italiana 2009/2.

Cecchetti, S.G., M.S. Mohanty, and F. Zampolli. 2010. “The future of public debt: prospects and implications.” BIS Working Paper no. 300.

Ciocca, P. 1987. "Between 'a Science' and 'an Art': Central Banks and the Political Economy of Money.” in P. Ciocca (ed.), Money and the Economy: Central Bankers’ Views. London: MacMillan.

Colander, D.C. 1997. "Functional Finance” in T. Cate, G. Harcourt, and D.C. Colandeal (eds.) An Encyclopedia of Keynesian Economics. Cheltenham: Edward Elgar.

. 2003. "Functional finance, new classical economics and great-great grandsons.” in E.J. Nell and M. Forstater (eds.), Reinventing Functional Finance Transformational Growth and Full Employment. Cheltenham: Edward Elgar.

Cottarelli, C., and C. Giannini. 1997. "Credibility without Rules? Monetary Framework in the PostBretton Woods Era.” Tema di Discussione della Banca d’Italia no. 313.

De Brunhoff, S., and P. Ewenczyk. 1981. La moneta e il credito. Milano: Feltrinelli.

De Grauwe, P. 2009. “Keynes’ Savings Paradox, Fisher’s Debt Deflation and the Banking Crisis.” CEPS Working Document no. 219.

Debelle, G. 2004. "Macroeconomic implications of rising household debt.” BIS Working Paper no. 153.

Desai, M. 1973. “Growth Cycles and Inflation in a Model of the Class Struggle.” Journal of Economic Theory 6(6).

Dobbs, R., S. Lund, T. Koller, and A. Shwayder. 2013. “QE and ultra-low interest rates: Distributional effects and risks.” McKinsey Global Institute. Available at: http://www.mckinsey.com/insights/economic_studies/qe_and_ultra_low_interest_rates_distr ibutional_effects_and_risks

Dobbs, R., S. Lund, J. Woetzel, and M. Mutafchieva. 2015. "Debt and not much deleveraging.” McKinsey Global Institute. Available at: http://www.mckinsey.com/insights/economic_studies/debt_and_not_much_deleveraging/

Draghi, M. 2012. "Speech by Mario Draghi, President of the European Central Bank at the Global Investment Conference in London.” July 26. Available at: https://www.ecb.europa.eu/press/key/date/2012/html/sp120726.en.html 
Farmer, J.D., and D. Foley. 2009. “The economy needs agent-based modelling.” Nature, August 6.

Forges Davanzati, G. 2009. “Il governo, la crisi e i costi sociali del rigore finanziario.” in Economia e Politica-Rivista on line di critica della politica economica, June 11. Available at: http://www.economiaepolitica.it/index.php/primo-piano/il-governo-la-crisi-e-i-costi-socialidel-rigore-finanziario/

Forstater, M. 2003. “Functional Finance and Full Employment: Lessons from Lerner for Today?” in E.J. Nell and M. Forstater (eds.), Reinventing Functional Finance Transformational Growth and Full Employment. Cheltenham: Edward Elgar.

Forster, J.D. 2009. “Keynesian Policies Stimulate Debate and Debt, Not Employment.” in CESifo Forum, n.2/2009.

Freixas X., and J. Rochet. 2008. Microeconomics of Banking. Cambridge, MA: MIT Press.

Garside, W.R. 1990. British Unemployment, 1919-1939: a study in public policy. Cambridge, UK: Cambridge University Press.

Goodhart, C.A.E. 1998. “The two concepts of money: Implications for the analysis of optimal currency areas.” European Journal of Political Economy 14: 407-32.

Gordon Childe, V. 1950 (2004). La rivoluzione urbana. Soveria Mannelli: Rubbettino.

Greenspan, A. 2007. The Age of Turbulence. London: Penguin Press.

—. 2009. "Inflation is the big threat to a sustained recovery.” Financial Times, June 26.

Haldane, A.G. 2010. “The \$100 Billion Question.” Comments given at the Institute of Regulation \& Risk, Hong Kong, March 30. Available at: http://www.bis.org/review/r100406d.pdf

Hayes, M.G. 2012. “Ingham and Keynes on the Nature of Money.” Post Keynesian Economics Study Group Working Paper no. 1209.

Herndon T., M. Ash, and R. Pollin. 2013. "Does High Public Debt Consistently Stifle Economic Growth? A Critique of Reinhart and Rogoff.” University of Massachussets Working Paper no. 322.

Ingham, G. 2001. "Fundamentals of a theory of money: untangling Fine, Lapavitsas and Zelizer.” Economy and Society 30:3

—. 2004. The Nature of Money. Cambridge, UK: Polity Press.

Jakab, Z., and M. Kumhof. 2015. "Banks are not intermediaries of loanable funds—and why this matters.” Bank of England Working Paper no. 529.

Katz, M.L., and C. Shapiro. 1985. "Network Externalities, Competition, and Compatibility.” American Economic Review 75(3).

Kay, J. 2009. "Narrow Banking: The Reform of Banking Regulation.” Mimeo. Available at: http://www.johnkay.com/wp-content/uploads/2009/12/JK-Narrow-Banking.pdf 
Keynes, J.M. 1936 (1973). “The General Theory of Employment, Interest, and Money.” in The Collected Writings, Vol. VII. London: Macmillan.

Kindleberger C.P., and R.Z. Aliber. 2005. Manias, Panics, and Crashes A History of Financial Crises. Hoboken, NJ: John Wiley \& Sons.

Koo, R.C. 2008. The Holy Grail of Macroeconomics: Lessons from Japan’s Great Recession. New York: Wiley \& Sons, Ltd.

Kumhof, M., and R. Rancière. 2010. “Inequality, Leverage and Crises.” IMF Working Paper no. $10 / 268$.

Kydland F.E., and E.C. Prescott. 1977. "Rules Rather Than Discretion: The Inconsistency of Optimal Plan.” The Journal of Political Economy 85(2).

Lerner, A.P. 1943. “Functional Finance and the Federal Debt.” Social Research 10: 38-51.

Liverani, M. 2004. Antico Oriente. Storia, società, economia. Bari: Laterza.

Lunghini, G. 1995. La società dello spreco. Torino: Boringhieri.

Mangano, G. 1998. "Measuring Central Bank Independence: a Tale of Subjectivity and of its Consequences.” Oxford Economic Papers 50(3).

Marotta, G., and G.B. Pittaluga .1993. La regolamentazione degli intermediari bancari. Bologna: Il Mulino.

Mastromatteo G., and L. Esposito. 2014. "Banking on ELR. How the ideas of Minsky can tackle unemployment.” Paper presented at the 55th Annual Conference of the Società Italiana degli Economisti, Trento.

Mazzucato, M. 2013. The Entrepreneurial State: debunking public vs. private sector myths. London: Anthem.

McLeay, M., A. Radia, and R. Thomas. 2014. “Money creation in the modern economy.” Bank of England Quarterly Bulletin, 1-2014. Available at:

http://www.bankofengland.co.uk/publications/Documents/quarterlybulletin/2014/qb14q1pre releasemoneycreation.pdf

Menichella, D. 1956. "The Contribution of the Banking System to Monetary Equilibrium and Economic Stability: Italian Experience.” in P. Ciocca (ed.) Money and the Economy: Central Bankers' Views. London: MacMillan.

Milano, L. 2012. Il Vicino Oriente antico dalle origini ad Alessandro Magno. Milano: Encyclomedia.

Minsky, H.P. 1982. Can “It” Happen Again? Essays on Instability and Finance. New York: M.E. Sharpe.

—. 1986a. Stabilizing an unstable economy. New Haven and London: Yale University Press. 
_. 1986b. “Global Consequences of Financial Deregulation.” The Marcus Wallenberg Papers on International Finance 2(1).

Musella, M. 1988. “Inflazione e conflitto sociale in un modello ‘alla Rowthorn.” Rivista di Politica Economica 78(12).

Musgrave, R.A. 1959. The Theory of Public Finance. New York: McGraw-Hill.

- 2003. "Functional finance and fiscal functions.” in E.J. Nell and M. Forstater (eds.), Reinventing Functional Finance Transformational Growth and Full Employment. Cheltenham: Edward Elgar.

Nell, E.J., and M. Forstater. 2003. Reinventing Functional Finance Transformational Growth and Full Employment. Cheltenham: Edward Elgar.

Nersisyan, Y., and L.R. Wray. 2010. "Does Excessive Sovereign Debt Really Hurt Growth? A Critique of 'This Time Is Different,' by Reinhart and Rogoff.” Levy Economics Institute of Bard College Working Paper n. 603.

OECD. 2014. “Policy Challenges for the Next 50 Years.” OECD Policy Paper No. 9.

Pasinetti, L. 1998. “The myth (or folly) of the 3\% deficit/GDP Maastricht parameter.” Cambridge Journal of Economics 22(1).

Perez, C. 2009. After crisis: creative construction, Open Democracy, OpenEconomy open-minded economics, March 5. Available at:

http://www.opendemocracy.net/article/economics/email/how-to-make-economic-crisiscreative

Ricardo, D. 1821 (2001). On the Principles of Political Economy and Taxation. Ontario: Batoche Books Kitchener.

Seccareccia, M. 2010a. “Is Functional Finance ‘Sound’ Long-Term Policy or Is There a Need for an 'Exit Strategy’ to Ensure Balanced Budgets?” Speech to the 44th Annual Conference of the Canadian Economics Association, Quebec City, May 29.

_ 2010b. "No to Fiscal Austerity. The Perils of Deflation and the Case for Functional Finance.” in Economia e Politica—Rivista on line di critica della politica economica, July 19. Available at: http://www.economiaepolitica.it/index.php/europa-e-mondo/no-to-fiscalausterity-the-perils-of-deflation-and-the-case-for-functional-finance/

Smith, A. 1776 (2007). An Inquiry into the Nature and Causes of the Wealth of Nations. Petersfield: Harriman House, Ltd.

Spilimbergo, A., S. Symansky, O. Blanchard, and C. Cottarelli. 2009. "Fiscal Policy for the Crisis.” CESifo Forum, no. 2/2009.

Suarez, F.F., and J.M. Utterback. 1995. "Dominant Designs and the Survival of Firms.” Strategic Management Journal 16: 415-43. 
Taccone, A. 2008. “Riforme economiche e scelte collettive.” Università Luiss—Guido CarliRoma— Dipartimento di Scienze Economiche e Aziendali, Quaderno n. 156.

Tatom, J.A. 2009. “The limits of fiscal policy.” CESifo Forum, n.2/2009.

Taylor, A.M. 2012. “The Great Leveraging.” NBER Working Paper no. 18290.

Tcherneva, P. 2008. "The Return of Fiscal Policy: Can the New Developments in the New Economic Consensus Be Reconciled with the Post-Keynesian View?” Levy Economics Institute of Bard College Working Paper n. 539.

Turner, A. 2009. The Turner Review: A regulatory response to the global banking crisis. London: FSA.

Varoufakis, Y. 2014. "Why Reinhart and Rogoff are wrong about the Eurozone’s debt structure and the costs of debt mutualisation.” Blog post. Available at:

http://yanisvaroufakis.eu/2014/01/08/why-reinhart-and-rogoff-are-wrong-about-theeurozones-debt-structure-and-the-costs-of-debt-mutualisation/

Wen, Y., and J. Wu. 2014. "Withstanding Great Recession like China.” Federal Reserve Bank of St. Louis Working Paper 2014-007A.

Wray, R.L. 2003. "Functional finance and US government budget surpluses in the new millennium.” in E.J. Nell and M. Forstater (eds.), Reinventing Functional Finance Transformational Growth and Full Employment. Cheltenham: Edward Elgar.

— 2004. Credit and State Theories of Money. Cheltenham: Edward Elgar.

— 2009a. “The Social and Economic Importance of Full Employment.” Levy Economics Institute of Bard College Working Paper n. 560.

—. 2009b. “The Return of Big Government_Policy Advice for President Obama.” Levy Economics Institute of Bard College Public Policy Brief no. 99.

—. 2009c. “An Alternative View of Finance, Saving, Deficits, and Liquidity.” Levy Economics Institute of Bard College Working Paper no. 580. 